\title{
Ocean Acidification Decreases Growth and Development in American Lobster (Homarus americanus) Larvae
}

\author{
Elise A. Keppel ${ }^{1}$, Ricardo A. Scrosati ${ }^{1 *}$ and Simon C. Courtenay ${ }^{2}$ \\ ${ }^{1}$ Saint Francis Xavier University, Department of Biology, Antigonish, \\ Nova Scotia B2G 2W5, Canada \\ ${ }^{2}$ Fisheries and Oceans Canada at the Canadian Rivers Institute, 10 Bailey Dr., \\ Fredericton, New Brunswick E3B 5A3, Canada
}

\begin{abstract}
Keppel, E. A., R. A. Scrosati and S. C. Courtenay. 2012. Ocean acidification decreases growth and development in American lobster (Homarus americanus) larvae. J. Northw. Atl. Fish. Sci., 44: 61-66. doi:10.2960/J.v44.m683
\end{abstract}

\begin{abstract}
Ocean acidification resulting from the global increase in atmospheric $\mathrm{CO}_{2}$ concentration is emerging as a threat to marine species, including crustaceans. Fisheries involving the American lobster (Homarus americanus) are economically important in eastern Canada and United States. Based on ocean $\mathrm{pH}$ levels predicted for 2100, this study examined the effects of reduced seawater $\mathrm{pH}$ on the growth (carapace length) and development (time to molt) of American lobster larvae throughout stages I-III until reaching stage IV (postlarvae). Each stage is reached after a corresponding molt. Larvae were reared from stage I in either acidified $(\mathrm{pH}=7.7)$ or control $(\mathrm{pH}=8.1)$ seawater. Organisms in acidified seawater exhibited a significantly shorter carapace length than those in control seawater after every molt. Larvae in acidified seawater also took significantly more time to reach each molt than control larvae. In nature, slowed progress through larval molts could result in greater time in the water column, where larvae are vulnerable to pelagic predators, potentially leading to reduced benthic recruitment. Evidence was also found of reduced survival when reaching the last stage under acidified conditions. Thus, from the perspective of larval ecology, it is possible that future ocean acidification may harm this important marine resource.
\end{abstract}

Keywords: Crustacea, Decapoda, Homarus, lobster, ocean acidification

(C) Her Majesty the Queen in right of Canada, 2012

\section{Introduction}

The increasing concentration of atmospheric carbon dioxide $\left(\mathrm{CO}_{2}\right)$ because of anthropogenic sources is driving an increase in ocean $\mathrm{CO}_{2}$ concentration. This is causing a decrease in seawater $\mathrm{pH}$ (ocean acidification), potentially putting additional stress on marine organisms already threatened by rising ocean temperatures (Pörtner et al., 2004; 2005; Raven et al., 2005; Widdicombe and Spicer, 2008). Ocean acidification has been acknowledged by the Intergovernmental Panel on Climate Change to have decreased seawater $\mathrm{pH}$ by 0.1 units since the industrial revolution (Meehl et al., 2007) and is predicted to result in a further decrease of 0.3-0.4 units by the end of this century (Caldeira and Wickett, 2005; Raven et al., 2005).

With the increase in ocean $\mathrm{CO}_{2}$ concentration, there is a concomitant decrease in carbonate saturation state (Feely et al., 2004; Orr et al., 2005). The outcome is lower concentration of carbonate ions available for the biosynthesis of calcium carbonate $\left(\mathrm{CaCO}_{3}\right)$ for building calcified body structures (e.g., shells), as well as higher rates of dissolution of $\mathrm{CaCO}_{3}$ from existing structures. Additionally, increased energetic costs for building and maintaining $\mathrm{CaCO}_{3}$ structures may pull resources from other important biological processes such as growth and reproduction. Therefore, calcifying organisms including mollusks (Michaelidis et al., 2005; Gazeau et al., 2007), echinoderms (Kurihara and Shirayam, 2004), and reefbuilding corals (Langdon and Atkinson, 2005; Doney et al., 2009) have been a strong focus of study in ocean acidification research, looking at a variety of effects on growth and reproduction (Doney et al., 2009; Hendriks et al., 2010; Kroeker et al., 2010). One of the dominant messages coming from this research is that there is a great deal of variability in responses to decreasing $\mathrm{pH}$ between, and even within, taxonomic groups (Ridgwell et al., 2009; Pistevos et al., 2011). 
American lobster (Homarus americanus) is a commercially important crustacean on the Atlantic coast of Canada and the United States. This species supports valuable fisheries, with annual landings of \$ 562 million in Canada (Fisheries and Oceans Canada, 2012) and \$ 228 million in the United States (Singer et al., 2012). Thus, anticipating potential effects of ocean acidification on lobster is relevant to predicting the sustainability of this resource. Crustaceans in general have received little attention on how they may respond to acidification, and research to date has reported variable results (Whiteley, 2011). In a recent study, larvae and postlarvae of the European lobster (Homarus gammarus) growing in seawater at $\mathrm{pH}$ levels predicted for 2100 exhibited less mineralization of the carapace (Arnold et al., 2009). Softer shells could put the lobster at greater risk for predation soon after molting (Factor, 1995) and may also reduce feeding ability through decreased strength of claws, which are more heavily calcified than the carapace to provide crushing strength for consuming prey (Bosselmann et al., 2007). Conversely, American lobster juveniles exhibited no change in calcification rates at $\mathrm{pH}$ levels predicted for 2100 (Ries et al., 2009). Other invertebrates, such as brittle stars (Echinodermata), have been shown to increase calcification rates with decreasing $\mathrm{pH}$, but have done so at the cost of reduced energy available for other processes. In Amphiura filiformis, this was seen as muscle wastage (Wood et al., 2008) and, in Ophiura ophiura, as reduced arm regeneration (Wood et al., 2010). This was not tested for American lobster, but maintenance of shell mineralization may reduce energy available for important processes such as growth and molting. Some life stages may be more sensitive to lower $\mathrm{pH}$ than others, and the most susceptible stage is species-specific (Kurihara, 2008). In particular, lobster larvae may be most sensitive to decreases in $\mathrm{pH}$ due to the frequent molting required during their development. Research on the effects of ocean acidification on the various life-history stages of American lobster is necessary to understand how they may respond to future conditions. Here, we present the results of an examination of the effects of $\mathrm{CO}_{2}$-induced acidification on American lobster larval growth and development at $\mathrm{pH}$ levels predicted for 2100. We hypothesized that larvae would exhibit reduced growth and development with reduced $\mathrm{pH}$.

\section{Materials and Methods}

We obtained stage-I larvae from the Pictou Lobster Hatchery and Museum (Pictou, Nova Scotia, Canada), where ovigerous females were supplied by local fishermen. Our experiment was carried out in June 2011, corresponding to the natural occurrence of lobster larvae in the Northumberland Strait, in the southern Gulf of
St. Lawrence, Canada. Larvae were transferred from the hatchery to the Marine Ecology Lab at Saint Francis Xavier University (Antigonish, Nova Scotia) within $3 \mathrm{~h}$ of hatching, and randomly distributed amongst experimental containers (15 larvae per container, 6 containers per each of $2 \mathrm{pH}$ treatments, 180 larvae in total) within minutes upon arrival to the lab. We placed 15 larvae per container to be able to have at least one organism to measure in each container at successive sampling dates, as we anticipated that mortality would occur during the experiment. Each container was supplied with 1 L of constantly aerated, filtered seawater from the Northumberland Strait (temperature $\sim 20^{\circ} \mathrm{C}$, salinity $\sim 31 \mathrm{psu}$ ). Seawater in each container was partially changed every two to three days. Molted exoskeletons and dead organisms (due to natural mortality or cannibalism) were removed as they occurred. Larvae were fed live brine shrimp (Artemia spp., 5 individuals $\mathrm{ml}^{-1}$ ) daily.

For the experiment, we considered two levels of seawater $\mathrm{pH}$ (control and acidified), which were produced by bubbling either ambient air or $\mathrm{CO}_{2}$-enriched air into each replicate container through diffusing stones during the entire experiment. $\mathrm{CO}_{2}$ concentrations of $400 \mathrm{ppm}$ and 1200 ppm were chosen to represent current conditions and year-2100 conditions (Meehl et al., 2007), respectively. This approach resulted in $\mathrm{pH}$ values of 8.1 for the control treatment and 7.7 for the acidified treatment. The $\mathrm{CO}_{2}-$ enriched air was produced by mixing ambient air with $\mathrm{CO}_{2}$, controlling flow rates with Sierra Instruments Smart Trak mass flow controllers (Provan Control Associates, Quebec, Canada). $\mathrm{CO}_{2}$ concentration was verified daily using a Qubit S151 $\mathrm{CO}_{2}$ analyzer (Qubit Systems, Ontario, Canada). Measurements of $\mathrm{pH}$ were recorded to the nearest 0.01 units with a pHep5 pH Tester (Hanna Instruments, Quebec, Canada) every second day for the duration of the experiment. With this setup, the two desired levels of $\mathrm{pH}$ remained stable during the experiment at the precision level needed for the study ( 0.1 units of $\mathrm{pH})$.

We evaluated the effects of seawater acidification on the growth and development of American lobster larvae throughout stages I-III until reaching stage IV (postlarvae). To assess effects on growth, we measured carapace length once larvae molted to each stage (day one of the experiment for stage I). To test for effects on development, we recorded the number of days to reach each successive molt. After all larvae reached each stage in a container ( $n=6$ containers per $\mathrm{pH}$ treatment), one individual was randomly selected from each container and its carapace length was measured out of the water using a dissecting microscope to the nearest $0.1 \mathrm{~mm}$. Number of days to reach the molt to each stage was 
also recorded, using one average value per container for data analyses whenever the larvae in that container molted at different days. We identified stages using morphological characteristics previously described for this species (Factor, 1995). After carapace measurements, the measured individuals were permanently removed from the experiment. We measured carapace length for one individual per container for each molt to prevent any handling effects (due to manipulation out of the water) from occurring on the individuals that were to be measured for growth and development at later dates. The experiment was terminated after all larvae molted to stage IV (day 13), as three containers in the acidified treatment then had no organisms left because of mortality between stages III and IV. We tested for acidification effects on growth and development using Student's $t$-tests done with SYSTAT 13.0 (SYSTAT, 2009), wherever applicable depending on the occurrence of data variation within molts (see Results). The $t$-test is a statistically robust procedure, especially when sample sizes for both treatments are equal (Mead, 1991); we used the separate-variances procedure (instead of the pooled-variance procedure) to calculate $t$ values to ensure reliable results.

\section{Results}

\section{Carapace length}

Carapace length (Fig. 1) was statistically similar in both $\mathrm{pH}$ treatments for stage-I larvae at the beginning of the experiment $(t=0.75, p=0.472)$, indicating an adequate random assignment of larvae to both treatments. Carapace length was, however, significantly lower in acidified seawater than in control seawater for each successive life-history stage: stage II $(t=8.95, p<0.001)$, stage III $(t=4.05, p=0.002)$, and stage IV $(t=2.88, p=0.024)$. All analyses were done using data for six individuals per treatment (one random individual per container), except for stage IV (postlarvae), since six individuals reached stage IV in the control treatment (one in each of the six containers) but only three individuals reached stage IV in the acidified treatment (one in each of three containers) because of mortality between stages III and IV.

\section{Development}

Cumulative number of days to molt to successive lifehistory stages was used to track development rates. Number of days to molt to stages II, III, and IV (Fig. 2) was always higher in acidified seawater. All stage-I larvae in control seawater molted to stage II at day two, while all stage-I larvae in acidified seawater molted to stage II at day five. The lack of within-treatment variation in both

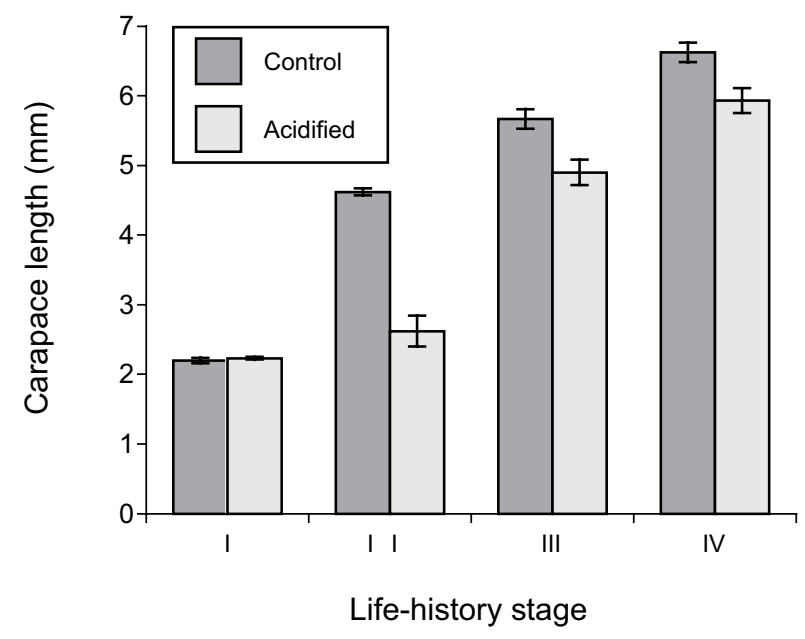

Fig. 1. Carapace length (mean $\pm \mathrm{SE}$ ) for the successive early life-history stages of American lobster grown in control and acidified seawater. Stages I-III correspond to larvae, while stage IV represents postlarvae.

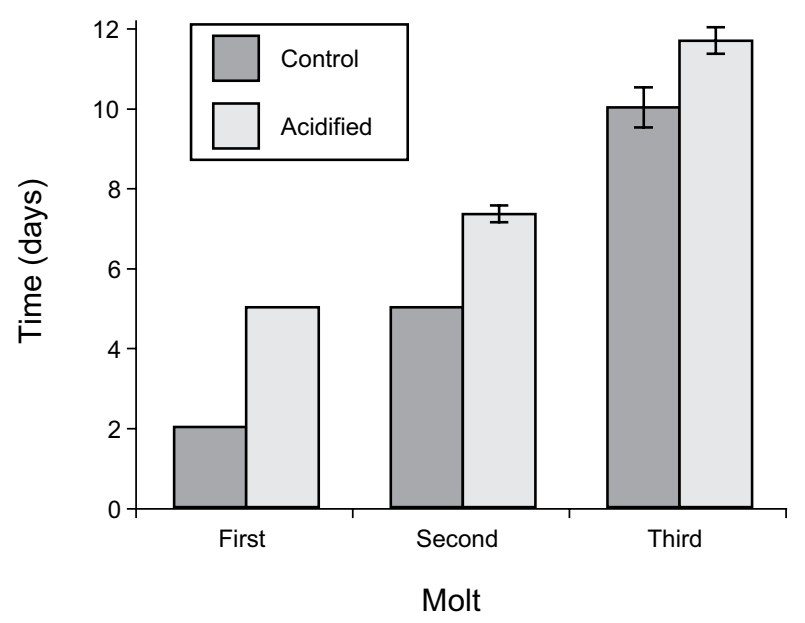

Fig. 2. Cumulative number of days (mean \pm SE where it corresponds; see Results) to reach successive molts for American lobster larvae grown in control and acidified seawater. The first molt occurs between larval stages I-II, the second molt between larval stages II-III, and the third molt between larval stage III and stage IV (postlarvae).

treatments prevented statistical tests from being done, but differences were evident, as molting in acidified conditions took more than twice the control time. All stage-II larvae in control seawater molted to stage III at day five, while stage-II larvae in acidified seawater molted to stage III at an average of 7.3 days, which was a significant difference $(t=11.07, p<0.001)$. Stage-III larvae in control seawater molted to stage IV (postlarvae) at an average of 10 days, 
while stage-III larvae in acidified seawater molted to stage IV at an average of 12 days, which was a significant difference $(t=2.42, p=0.046)$. As noted above, only three stage-III larvae (one per container) survived and molted to stage IV in acidified seawater, while the last six stage-III larvae in control water (one per container) molted to stage IV.

\section{Discussion}

Negative species responses to ocean acidification have been commonly found in marine invertebrates. Here, it is shown that American lobster larvae exhibit reduced rates of growth and development under the lower levels of seawater $\mathrm{pH}$ predicted for 2100 , compared with current levels. Similar responses have been observed for other marine invertebrates, such as sea stars, mussels, and corals (Fabry et al., 2008). Crustacean examples include the shrimp Pandalus borealis, which displayed increased development time under acidified conditions (Bechmann et al., 2011), and the spider crab Hyas araneus, which displayed both decreased growth and development rates (Walther et al., 2010), although pH levels were not always exactly the same across studies.

American lobster larvae may respond to decreased $\mathrm{pH}$ with reduced growth and development rates as a result of reallocation of energy to other processes. Such a response has been seen in brittlestars, which displayed muscle wastage (Amphiura filiformis, Wood et al., 2008) or a reduced ability to regenerate lost limbs (Ophiura ophiura, Wood et al., 2010) while maintaining growth of calcified structures in acidified seawater. This suggests that maintenance of calcified structures may occur at the cost of somatic tissue loss or alterations to other biological processes, possibly implying indirect effects on fitness and survival. In lobster larvae, additional energy may be allocated to powering proton pumps for maintenance of internal acid-base balance or mineralization of the calcified exoskeleton (Pörtner et al., 2004), reducing investment in growth and delaying the energy-expensive molting process. Effects of decreased $\mathrm{pH}$ on calcification of the exoskeleton in American lobster larvae remain to be tested, although it was recently reported that juveniles exhibit no change in calcification rates at $\mathrm{pH}$ levels predicted for 2100 (Ries et al., 2009). While different life-history stages of some species may respond differently to acidification (Kurihara, 2008), our results on lobster larvae fit well with results for juveniles, with reductions in larval growth possibly resulting from maintenance of calcification rates in an acidified environment. Research is required on the effects of ocean acidification on calcification in lobster larvae and on growth in juveniles to test this possibility.
The slower growth and development of American lobster larvae under acidified conditions results in delays to reaching each molt, including the key metamorphosis from stage III (last larval stage) to stage IV (postlarvae), which marks the transition from a pelagic to benthic life. A delay in this transition extends the time spent in the water column, where there is little protection from predation (Factor, 1995), which might lead to an increase in predation-related mortality. This, as well as an increase in mortality unrelated to predation between stages III and IV, as found towards the end of our experiment, might lead to reduced lobster recruitment to the seafloor and subsequent reductions in populations.

Our results differ from those for European lobster (H. gammarus) larvae, as their growth rate remained unaffected by acidification between stages I-IV (Arnold et al., 2009). That study also found a decrease in carapace mineral content (magnesium) for stage-III larvae in acidified seawater. These results suggest an emerging pattern of differing responses to ocean acidification within taxonomic groups (Ridgwell et al., 2009; Pistevos et al., 2011). Larvae of $H$. gammarus might maintain growth rates at the cost of reduced carapace mineralization. Similarly, adult velvet swimming crab (Necora puber) was also found to decrease exoskeletal mineralization in acidified seawater due to partial dissolution of its shell to compensate for extracellular acidosis (Spicer et al., 2007; Small et al., 2010). Decreased calcification has also been seen in other taxonomic groups in response to acidification (e.g., corals, Kleypas and Yates, 2009, and coccolithophores, Beaufort et al., 2011), although tested conditions were not always identical among studies. Response differences between closely related species emphasize the need for research on a range of organisms from various geographic ranges. In doing so, it will be important to test for the same range of abiotic values to facilitate comparisons.

Overall, our results suggest that American lobster larvae may exhibit reduced performance in response to ocean acidification at $\mathrm{pH}$ levels predicted for 2100 . It remains to be tested whether reduced growth and development would also occur in juveniles and adults. Effects on fertility and hatching also require investigation. Since some crustaceans (e.g., crabs) decrease thermal tolerance at lower pH (Metzger et al., 2007; Walther et al., 2009), the interactive effects of acidification and rising temperature should be investigated as well. It is also unknown whether lobsters have the potential for adaptation to predicted ocean conditions to some extent. These key questions need investigation in order to best inform industry, policy- 
makers, and conservation programs on possible future scenarios. From the perspective of larval ecology, our study suggests that future ocean acidification may harm this important marine resource.

\section{Acknowledgements}

We thank Christopher Harley and Jocelyn Nelson for introducing us to acidification experiments, Sean Mitchell, Julius Ellrich, and two anonymous reviewers for providing helpful comments on the manuscript, and Terry MacGrath and the Pictou Lobster Hatchery for donating larvae and offering handling advice. Research was funded by grants awarded to R.A.S. by the Canada Research Chairs program (CRC), the Canada Foundation for Innovation (CFI), and the Natural Sciences and Engineering Research Council (NSERC, Discovery Grant) and by a grant awarded to S.C.C. by Fisheries and Oceans Canada (DFO).

\section{References}

ARNOLD, K. E., H. S. FINDLAY, J. I. SPICER, C. L. DANIELS and D. BOOTHROYD. 2009. Effect of $\mathrm{CO}_{2}$-related acidification on aspects of the larval development of the European lobster, Homarus gammarus (L.). Biogeosciences, 6: 1747-1754. http://dx.doi.org/10.5194/bg-6-1747-2009

BEAUFORT, L., I. PROBERT, T. de GARIDEL-THORON, E. M. BENDIF, D. RUIZ-PINO, N. METZL, C. GOYET, N. BUCHET, P. COUPEL, M. GRELAUD, B. ROST, R. E. M. RICKABY and C. DE VARGAS. 2011. Sensitivity of coccolithophores to carbonate chemistry and ocean acidification. Nature, 476: 80-83. http://dx.doi. org/10.1038/nature10295 PMid:21814280

BECHMANN, R. K., I. C. TABAN, S. WESTERLUND, B. F. GODAL, M. ARNBERG, S. VINGEN, A. INGVARSDOTTIR and T. BAUSSANT. 2011. Effects of ocean acidification on early life stages of shrimp (Pandalus borealis) and mussel (Mytilus edulis). J. Toxicol. Envir. Health, 7: 424-438. http://dx.doi. org/10.1080/1528739.2011.550460 PMid:21391089

BOSSELMANN, F., P. ROMANO, H. FABRITIUS, D. RAABE and M. EPPLE. 2007. The composition of the exoskeleton of two Crustacea: the American lobster Homarus americanus and the edible crab Cancer pagurus. Thermochimica Acta, 463: 65-68. http://dx.doi.org/10.1016/j.tca.2007.07.018

CALDEIRA, K. and M. E. WICKETT. 2005. Ocean model predictions of chemistry changes from carbon dioxide emissions to the atmosphere and ocean. J. Geophys. Res., 110: C09S04. http://dx.doi.org/10.1029/2004JC002671

DONEY, S. C., V. J. FABRY, R. A. FEELY and J. A. KLEYPAS. 2009. Ocean acidification: the other $\mathrm{CO}_{2}$ problem. Annu. Rev. Mar. Sci., 1: 169-192. http://dx.doi.org/10.1146/ annurev.marine.010908.163834

FABRY, V. J., B. A. SEIBEL, R. A. FEELY and J. C. ORR.
2008. Impacts of ocean acidification on marine fauna and ecosystem processes. ICESJ. Mar. Sci., 65: 414-432. http:// dx.doi.org/10.1093/icesjms/fsn048

FACTOR, J. R., 1995. Biology of the lobster Homarus americanus. Academic Press, San Diego, 528 p.

FEELY, R. A., C. L. SABINE, K. LEE, W. BERELSON, J. KLEYPAS, V. J. FABRY and F. J. MILLERO. 2004. Impact of anthropogenic $\mathrm{CO}_{2}$ on the $\mathrm{CaCO}_{3}$ system in the oceans. Science, 305: $362-366$.

FISHERIES AND OCEANS CANADA, 2012. Commercial fisheries. Available from http://www.dfo-mpo.gc.ca/stats/ commercial-eng.htm (last accessed on 25 June).

GAZEAU, F., C. QUIBLIER, J. M. JANSEN, J. P. GATTUSO, J. J. MIDDELBURG and C. H. R. HEIP. 2007. Impact of elevated $\mathrm{CO}_{2}$ on shellfish calcification. Geophys. Res. Lett., 34: L07603. http://dx.doi.org/10.1029/2006GL028554

HENDRIKS, I. E., C. M. DUARTE and M. ÁLVAREZ. 2010. Vulnerability of marine biodiversity to ocean acidification: a meta-analysis. Estuar., Coast. Shelf Sci., 86: 157-164. http://dx.doi.org/10.1016/j.ecss.2009.11.022

KLEYPAS, J. A. and K. K. YATES. 2009. Coral reefs and ocean acidification. Oceanography, 22: 108-117. http://dx.doi. org/10.5670/oceanog.2009.101

KROEKER, K. J., R. L. KORDAS, R. N. CRIM and G. G. SINGH. 2010. Meta-analysis reveals negative yet variable effects of ocean acidification on marine organisms. Ecol. Lett., 13: 1419-1434. http://dx.doi.org/10.1111/j.14610248.2010.01518.x PMid:20958904

KURIHARA, H. 2008. Effects of $\mathrm{CO}_{2}$-driven ocean acidification on the early developmental stages of invertebrates. Mar. Ecol. Prog. Ser., 373: 275-284. http://dx.doi.org/10.3354/ meps07802

KURIHARA, H. and Y. SHIRAYAM. 2004. Effects of increased atmospheric $\mathrm{CO}_{2}$ on sea urchin early development. Mar. Ecol. Prog. Ser., 274: 161-169. http://dx.doi.org/10.3354/ meps 274161

LANGDON, C. and M. J. ATKINSON. 2005. Effect of elevated $\mathrm{pCO}_{2}$ on photosynthesis and calcification of corals and interactions with seasonal change in temperature/irradiance and nutrient enrichment. J. Geophys. Res., 110: C09S07. http://dx.doi.org/10.1029/2004JC002576

MEAD, R. 1991. The design of experiments. Statistical principles for practical applications. Cambridge University Press, Cambridge, $620 \mathrm{p}$.

MEEHL, G. A., T. F. STOCKER, W. D. COLlins, P. FRIEDLINGSTEIN and A. T. GAYE. 2007. Climate change 2007: the physical science basis. Contribution of working group I to the fourth assessment report of the Intergovernmental Panel on Climate Change. Cambridge University Press, Cambridge.

METZGER, R., F. J. SARTORIS, M. LANGENBUCH and H. O. PÖRTNER. 2007. Influence of elevated $\mathrm{CO}_{2}$ concentrations on thermal tolerance of the edible crab Cancer pagurus. J. Thermal Biol., 32: 144-151. http://dx.doi.org/10.1016/j. jtherbio.2007.01.010

MICHAELIDIS, B., C. OUZOUNIS, A. PALERAS and H. O. PÖRTNER. 2005. Effects of long-term moderate 
hypercapnia on acid-base balance and growth rate in marine mussels (Mytilus galloprovincialis) Mar. Ecol. Prog. Ser., 93: 109-118. http://dx.doi.org/10.3354/meps293109

ORR, J. C., V. J. FABRY, O. AUMONT and L. BOPP. 2005. Anthropogenic ocean acidification over the twenty-first century and its impact on calcifying organisms. Nature, 437: 681-686. http://dx.doi.org/10.1038/nature04095 PMid:16193043

PISTEVOS, J. C. A., P. CALOSI, S. WIDDICOMBE and J. D. D. BISHOP. 2011. Will variation among genetic individuals influence species responses to global climate change? Oikos, 120: 675-689. http://dx.doi.org/10.1111/j.16000706.2010.19470.x

PÖRTNER, H. O., M. LANGENBUCH and B. MICHAELIDIS. 2005. Synergistic effects of temperature extremes, hypoxia and increases in $\mathrm{CO}_{2}$ on marine animals: from Earth history to global change. J. Geophys. Res., 110: C09S10. http:// dx.doi.org/10.1029/2004JC002561

PÖRTNER, H. O., M. LANGENBUCH andA. REIPSCHLÄGER, 2004. Biological impact of elevated ocean $\mathrm{CO}_{2}$ concentrations: lessons from animal physiology and earth history. J. Oceanogr., 60: 705-718. http://dx.doi. org/10.1007/s10872-004-5763-0

RAVEN, J., K. CALDEIRA, H. ELDERFIELD, O. HOEGHGULDBERG, P. LISS, U. RIEBESELL, J. SHEPHERD, C. TURLEY and A. WATSON. 2005. Ocean acidification due to increasing atmospheric carbon dioxide. Policy document 12/05. The Royal Society, London, $57 \mathrm{p}$.

RIDGWELL,A., D. N. SCHMIDT, C. TURLEY,C. BROWNLEE, M. T. MALDONADO, P. TORTELL and J. R. YOUNG. 2009. From laboratory manipulations to Earth system models: scaling calcification impacts of ocean acidification. Biogeosciences, 6: 2611-1623. http://dx.doi. org/10.5194/ bg-6-2611-2009

RIES, J. B., A. L. COHEN and D. C. McCORKLE. 2009. Marine calcifiers exhibit mixed responses to $\mathrm{CO}_{2}$-induced ocean acidification. Geology, 37: 1131-1134. http://dx.doi. org/10.1130/G30210A.1

SINGER, L. T. 2012. Maine Department of Marine Resources, Coastal Fishery Research Priorities, Lobster (Homarus americanus). Available from http://www.maine.gov/dmr/ research/priorities 10 (last accessed on 25 June).

SMALL, D., P. CALOSI, D. WHITE, J. I. SPICER and S. WIDDICOMBE. 2010. Impact of medium-term exposure to $\mathrm{CO}_{2}$-enriched seawater on the physiological functions of the velvet swimming crab Necora puber. Aq. Biol., 10: 11-21.

SPICER, J. I., A. RAFFO and S. WIDDICOMBE. 2007. Influence of $\mathrm{CO}_{2}$-related seawater acidification on extracellular acid-base balance in the velvet swimming crab Necora puber. Mar. Biol., 151: 1117-1125. http://dx.doi. org/10.1007/s00227-006-0551-6

SYSTAT. 2009. SYSTAT for Windows, Version 13.0. SYSTAT Software Inc., Richmond, California.

WAlTHER, K., K. ANGER and H. O. PÖRTNER. 2010. Effects of ocean acidification and warming on the larval development of the spider crab Hyas araneus from different latitudes $\left(54^{\circ}\right.$ vs. $79^{\circ}$ N). Mar. Ecol. Prog. Ser, 417: 159-170. http://dx.doi.org/10.3354/meps08807

WALTHER, K., F. J. SARTORIS, C. BOCK and H. O. PÖRTNER. 2009. Impact of anthropogenic ocean acidification on thermal tolerance of the spider crab Hyas araneus. Biogeosciences, 6: 2207-2215. http://dx.doi. org/10.5194/bg-6-2207-2009

WHITELEY, N. M. 2011. Physiological and ecological responses of crustaceans to ocean acidification. Mar. Ecol. Prog. Ser., 430: 257-271. http://dx.doi.org/10.3354/meps09185

WIDDICOMBE, S. and J. I. SPICER. 2008. Predicting the impact of ocean acidification on benthic biodiversity: what can animal physiology tell us? J. Exp. Mar. Biol. Ecol., 366: 187-197. http://dx.doi.org/10.1016/j.jembe.2008.07.024

WOOD, H. L., J. I. SPICER, D. M. LOWE and S. WIDDICOMBE. 2010. Interaction of ocean acidification and temperature: the high cost of survival in the brittlestar Ophiura ophiura. Mar. Biol., 157: 2001-2013. http://dx.doi.org/10.1007/ s00227-010-1469-6

WOOD, H. L., J. I. SPICER and S. WIDDICOMBE. 2008. Ocean acidification may increase calcification rates, but at a cost. Proc. Royal Soc. B, 275: 1767-1773. http://dx.doi. org/10.1098/rspb.2008.0343

PMid:18460426 PMCid:2587798 